\title{
ELUCIDATION OF THE INDIAN SALWAR KAMEEZ
}

\author{
Monisha Kumar ${ }^{1}$ and Amita Walia ${ }^{2}$ \\ ${ }^{1}$ Assist. Prof., Dar Al Hekma University, Saudi Arabia, monisha_73@yahoo.com \\ ${ }^{2}$ Assist. Prof. Dr., University of Delhi, India, dr.amitawalia@gmail.com
}

\begin{abstract}
In the recent years the Salwar Kameez has become an integral part of women's costume in the Indian subcontinent. Yet only a few are aware of its true origin. Even though the bifurcated and stitched garments were popularly worn during the slave dynasty, these costumes became more predominant and influential by the advent of the Mughals. The present day Salwar Kameez, also popular as one of the traditional Indian costumes today, traces back its origin to the Persian influence which was brought to India by the Mughals who followed Islam. This exchange of cultures with reference to the Salwar Kameez is an interesting aspect for study which focuses on the connection of these two different worlds. The Salwar Kameez has since then been transformed into various styles to develop it as a trendy yet comfortable costume for the modern Indian woman. The costume, once worn only by the Muslim women across the subcontinent, is now popular among the women of all faith and ages. This research aims to study the introduction of the Salwar Kameez in the Indian subcontinent and its gradual acceptance into the Indian culture. The author also studies the style adaptations of the Salwar Kameez in the various Indian states as well as in the subcontinent. The exchange of styles across the subcontinent is also studied and analyzed by the author.
\end{abstract}

Keywords: Origin, adaptation, clothing, salwar kameez, subcontinent.

\section{INTRODUCTION}

The Indus Valley civilization thrived near the Indus River, the North-western part of Indian subcontinent around $2300-1700 \mathrm{BC}$. Evidences show that the city was quite ahead of its times and well organized. The people had trade and commerce with the Persian Gulf. Archaeological evidences have shown draped cloak/shawl was worn by men and women wore short skirt with elaborate headgear and coiffure. The Indus Valley Civilization spreading from the Indus plains to Rajasthan \& Kathiawar region shows clear evidence of draped garments both by men \& women. From the post Vedic times till the Mauryan dynasty, the garments were draped and unstitched consisting mainly of Antariya- lower garment, Uttariya- upper garment, Kayabandh- a sash to hold the Antariya. In addition, women also wore a Patka- a decorative strip tucked in the center of the Antariya.

The main objectives of the research were to study the origin of Salwar Kameez, its introduction in the Indian subcontinent, its various style developments and the comparison of styles within the subcontinent. 


\section{ORIGIN OF SALWAR KAMEEZ}

The origin of Salwar Kameez cannot be exactly isolated in one country. With the emergence of Islam in the Middle East and Arab peninsula, the style of clothing was clearly defined for both men and women. Islamic dress has for centuries been used to symbolize purity, mark status or formal roles, distinguish believer from nonbeliever and identify gender. The word 'salwar' has been used to describe a loose fitted trousers fastened by a drawstrings at the waist in Turkey, Persia and the Arab world. The shalwar (Persian), šalvār (Turkish), sirwāl (Arabic) are a form of baggy trousers. The word 'kameez' is originally Arabic and is sometimes spelt as qameez or qamis. This is used to describe a shirt usually of varied lengths. Therefore it can be easily interpreted that the origin of the garment salwar kameez is either Persian or Arabic. Arab dress can be seen from northern Syria to North Africa. The basic dress of both men and women is based on the simple tunic, an unfitted garment pulled on over the head, common in the region since Roman times (qamis or thawb) Turkic dress was widely influential throughout the Islamic world. The Seljuk Turks emerged from Central Asia, establishing dynasties in Iran and Asia Minor by the eleventh century. By the midsixteenth century the Ottoman Turkish Empire encompassed most of the lands surrounding the Eastern Mediterranean. The traditional Turkish ensemble for either men or women consisted of loose fitting trousers (şalvar, don) and a shirt (gömlek), topped by a variety of jackets (cebken), vests (yelek), and long coats (entâri, kaftan, üç etek). Layering of garments was an important aesthetic element (Jirousek, 2004).

The 500 year Ottoman rule throughout the Arab world resulted in blending of garment forms, particularly in northern Arab regions adjacent to Anatolia, and also in urban Arab centers of the Eastern Mediterranean and North Africa. The adoption of buttoned vests or jackets of silk or wool decorated with embroidery, and the loose fitting trousers called şalvar in Turkish or sirwāl in Arabic are evidence of such borrowings in Arab dress. Traditional dress of Iran and Afghanistan along with that of Turkey is indicative of nomadic origins, with layered coats and şalvar as typical features of dress. These forms were also introduced into Muslim Northern India from Central Asia by the Turkic Gaznevids in the eleventh and twelfth century and by the Mughuls in the sixteenth century. Such forms are reflected in Mughul court dress, where for men trousers (paijama) were typically combined with front-opening coats or jackets of varying length and cut (angarkha or jama). For women, the characteristic ensemble might include a bodice or tunic (kurta or choli) and skirt (gaghra), and/or trousers (salwar), as well as a veil.

\section{INTRODUCTION TO THE INDIAN CULTURE}

It's been recorded and well documented in the history of costumes that the draped garments have been predominant in the Indian subcontinent throughout history. By the end of Gupta period, stitched garments like the Choli and Ghagra were being used; still the royalty continued wearing the draped garments- Antariya and Uttariya. The slave dynasty, during the 1100AD, introduced bifurcated garments both for men and women in the Indian subcontinent. Following the Afghan and Mughal invasions, there were significant changes in the costumes for both men and women. The costume of the Muslim women- the trouser, kaftan and the head cover (scarf) gradually became a part of the Indian costume, which after many transitions, is now popularly known as the Indian Salwar Kameez. The ancient Indian costumes were mostly draped garments consisting of Antariya, Utariya and Kayabandh. Even though the bifurcated and stitched garments were popularly worn during the slave dynasty, these costumes became more predominated and influenced by the impact of the Mughals. The present day Salwar Kameez, popular as one of the traditional Indian costume, traces back its origin to the Persian influence which was brought to India by the Mughals who followed Islam.

With the establishment of Mughal rule, a blend of Persian and ancient Indian artistic sensibilities can be seen in art, architecture and clothing. With the Persian influence, the majority of stitched garments entered India, the Antariya was replaced by the Pyjamas or costumes for the legs, which were of a various types, ranging from very loose to very tight; there were different types of Pyjamas for men and women, the cut, style and ornamentation also varied. The Uttariya still remained though various tunics like Kurtas and Angrakhas were added. The Persian men and women covered themselves from Head to Toe in various layers of stitched garments. It is interesting to note that in spite of such major influences, the majority of Indians continued to wear their traditional unstitched garments. A lot of fusion wear came in, like wearing Kurta with Dhoti (which is considered traditional Indian wear today), Kurta with various types of Pyjamas. The Maratha and Rajput men took to wearing the costumes influenced highly by the Mughal rulers, whereas the women continued to wear their traditional garments. A major change in the women's costume that came was the veil. Never before do we see women of the Indian subcontinent, covering their faces in veils. Only after the coming in of Islam, and its influence woman started covering their face, although they continue to wear their traditional Ghagra-Choli, Antariya-Uttariya blend - the Sari. Mughal women wore layers of clothing and also 
covered their faces with veils. It may be noted that based on the climate the clothing was cotton, lose and breathable (Gupta, 2011).

\subsection{Style Variations}

Under the domination of Iranian and Turkish people in Central Asia; Salwar Kameez as an expression of Indian ethnicity made its presence felt for the very first time. Research and historical records have proved that the pattern prevalent today in India was indeed the descendant of Turkish and Persian forms of Salwar Kameez. Unlike any other Indian dress, Salwar Kameez has transformed over time. With its pristine origin hinting at the Mughal courtroom this dress is almost synonymous with the Indian National dress along with the sari. The Salwar Kameez has become popular among the young generation because it's comfortable, elegant and most respected apparel. Over the decades the Salwar Kameez has been the focus of many designers and has been transformed as per the prevalent fashion trends. The journey was long, yet rich. Consequently, what followed are a series of styles and designs, varied materials and patterns to suit the changing taste of India (Ho, 2013).

\subsubsection{Salwar}

Indian Salwar resemble a Pajama drawn tightly in at the waist with a string and is tailored in such a way that it tapers at the ankles. The Indian Salwar has seen a lot more style variations than the Kameez.

> Salwar- A very simple and common pattern for a loose fitted trouser. The Salwar is cut in two pieces for each leg; front piece is cut straight and the back is cut at an angle adjusting the amount of looseness preferred by the wearer. Some people also refer this type of Salwar as Kunda Salwar. The excess fabric at the waist is gathered from the front and the back into a belt fitting the waist measurement of the wearer. At the ankle, the Salwar narrows down into a cuff known as Pauncha which is normally stiffened by the use of interlining. Any kind of fabric can be used for making this style of Salwar.

$>$ Patiala Salwar- Patiala Salwar (also called a Pattian walee Salwar) is a type of female trousers which has its roots in Patiala City in the Northern region of Punjab state in India. The King of Patiala in earlier times had its Royal dress as Patiala Salwar. Over the decade the dress now is not worn by men but has classically transformed itself with new cuts and styling into women's Patiala Salwar. Unlike the Salwar, the Patiala Salwar is a very loose form of trousers especially from the calf region of the leg and narrows down a little to a cuff at the ankle. . Since the Patiala Salwar is very loose and stitched with pleats it's a very comfortable outfit to wear. Patiala Salwar require double the length of material to get stitched. The fall of the pleats of the Patiala Salwar is such that it gives a beautiful cowl effect at the back. The popular fabrics for the Patiala Salwar are light weight fabrics like georgette and cotton lawn.

> Churidar- The word "Churidar" is a Hindi word which combines two words- Churi meaning bangle and Dar meaning like; hence the word Churidar means bangle like. The Churidar is cut longer than the length of the leg and is fitted from the hip to the ankle. The fabric is cut on the bias to give the necessary ease while sitting and movement. This is a very popular style among the young generation and is now a classic fashion. Fabrics commonly used for Churidars are cotton and silk. These days the Churidars are made from knitted fabrics which provide the required fit as well as the ease of movement while sitting and bending the legs.

$>$ Slim Pants- A very contemporary version of the Churidar is the Slim Pants. These are constructed exactly like a trouser and are fitted from the thigh and the calf areas of the leg and narrow down at the ankle. The slim pants are normally ankle length or a little above the ankle. Unlike the Churidar, slim pants are shorter in length and are cut on a straight grain. The slim pants are the current trend and are mostly embellished with embroidery at the ankle or with buttons. Some slim pants also come with trouser pockets and have a zipper closure in the front. The popular fabrics for slim pants are Poplin cotton or stretch cotton.

$>$ Palazzos- Again a very contemporary version of the Salwar which is more like a Pyjama with no cuff at the ankle and belt at the waist. These are elasticated at the waist and hang very loose from the hip area till the ankle. Sometimes the flare at the ankle is more giving a look like an A-line skirt. It can be inferred that Palazzos are stylised Pakistani Salwar, where the latter is loose but very straight from hip till the ankle.

D Dhoti Salwar- Dhoti Salwar can also be called a cowl Salwar as it is made on a bias. The extra fabric at the waist is carefully pleated into the waistband from the front and the back which makes the fabric 
fall on the outer seam of the Salwar giving a cowl effect on the sides. The Dhoti Salwar is a fusion of Dhoti; a lower garment draped around the legs by men during sacred ceremonies and a Salwar which is a stitched garment. The length of Dhoti Salwar is till the ankle and the hem does not end in the cuff (Pauncha). The best fabrics for this style are light to medium weight fabrics which drape well.
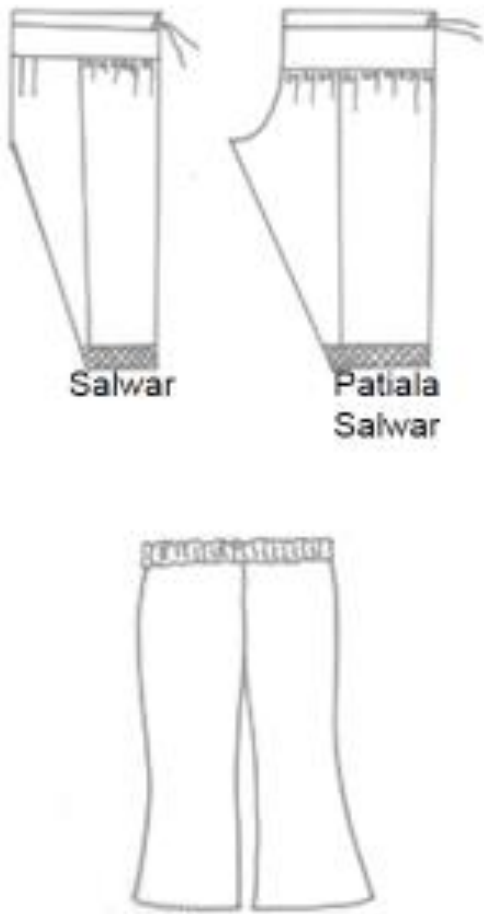

Palazzos
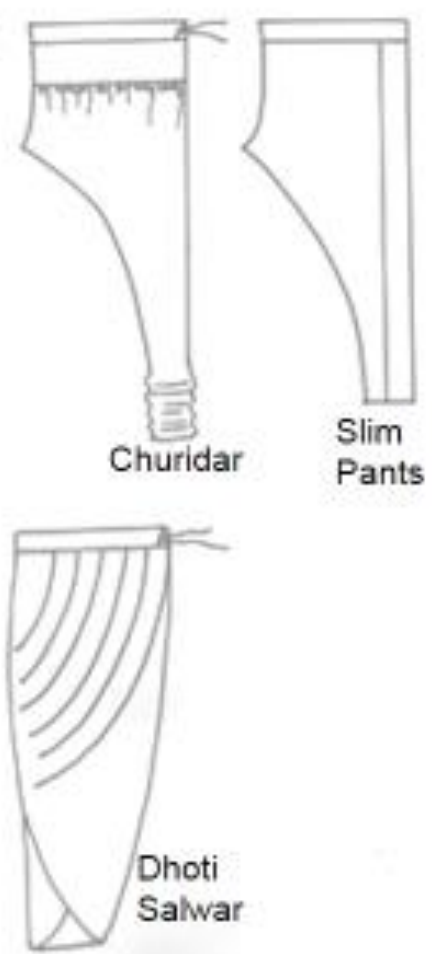

Fig. 1 Different Variations of Salwar worn in India

\subsubsection{Kameez}

The traditional Kameez top is a loose-fitting, knee-length tunic with long sleeves. The tunic is worn by pulling it over the head through a round neckline that has a front slit. The Kameez is worn over the Salwar and the complete outfit is commonly referred to as Salwar suit in India. Just like the Salwar, even the Kameez has seen a lot of style variations over the decades and has been called by various names.

$>$ Kameez- Ideally Kameez is a fitted knee length tunic which is worn with a Salwar. For a better fit front and back has a double faced dart (fish dart) at the waist along with the bust dart in the front of the garment. The garment has slits on both sides. Sometimes the length of the Kameez may be much above the knee. The length of the sleeve may vary according to the prevalent trend. Popular fabrics for the Kameez are cotton, silk, polyester and blended fabrics.

$>$ Kurta- A Kurta is a variation of Kameez which is slightly loose fitted with no shape at the waist and the hip. No darts are given in the front of the garment but sometimes double faced darts are given at the back for a better fit. A Kurta also has a slit on the sides. Usually Kurta is a loose fitted garment and can be worn with a Salwar, Churidar and now days with the Palazzos and Slim pants too. Since it is loose fitted, any kind of fabric can be used to construct a Kurta.

$>$ Kalidar Kurta- A Kalidar Kurta is similar to a frock and has six panels (three in the front and three at the back). The Kalidar Kurta is made up of several geometrical pieces. It has two rectangular central panels in the back and the front. The Kalidar Kurta is worn by both men and women. This style usually has long and loose sleeves. Pure cotton or cotton blend is the best suited fabric for this style.

$>$ Anarkali- Anarkali suit is made up of a long, frock-style top and got its name from a popular court dancer named Anarkali. This is a flared tunic and is normally till the ankle length but the waist of the wearer is accentuated to give a very classy look. Various panels are stitched together to give the required frock like flare. This style does not have slits on the sides. It is worn over a Churidar where only the folds (Churis) are visible while walking. The Anarkali suit is a timeless style which has become very popular. Light weight fabrics with a very good drape are ideal for this kind. 
> Angrakha- The term Angarkha is derived from the Sanskrit word Angarakșaka, which means protection of the body. It refers to traditional upper garment worn in the Indian Subcontinent which overlaps and is either tied to the left or right shoulder. It seems to have its origin from the 'Jama' which was a long coat worn by Mughals. The Angrakha style for women has been adapted from this. The top is normally loose fitted and one side overlaps the other and is tied at the chest level by means of strings. The Angrakha style may or may not have a slit on the sides. Angrakha is normally knee length which is flared; kind of A-line and usually with long or three quarter length sleeves. The Angrakha style is worn with a Churidar. Any kind of medium weight fabric can be used for making Angrakha style.
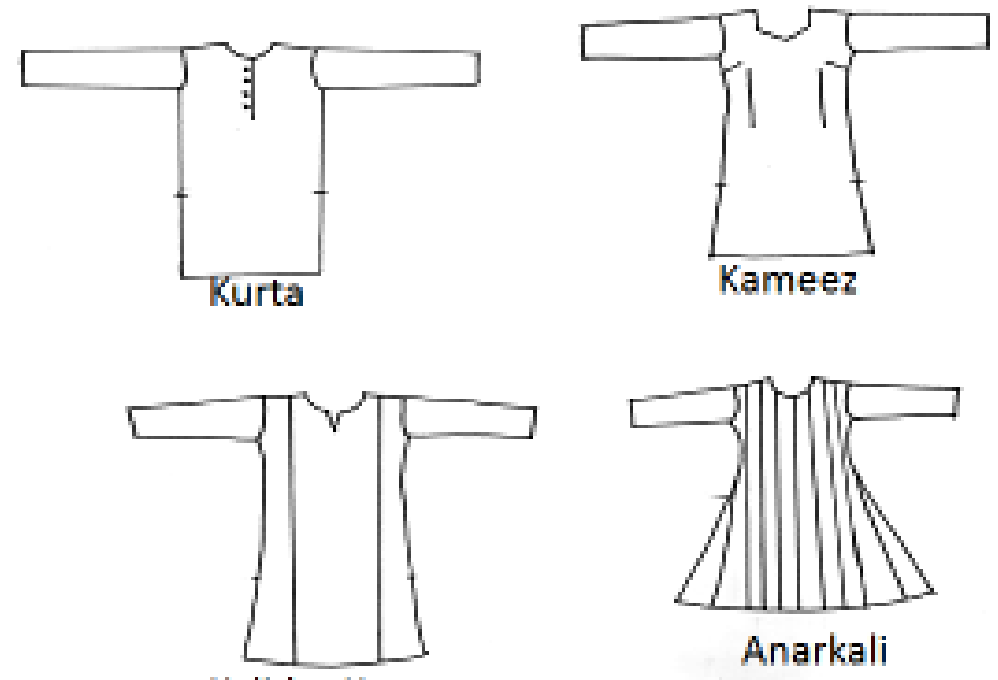

Kalidar Kurta

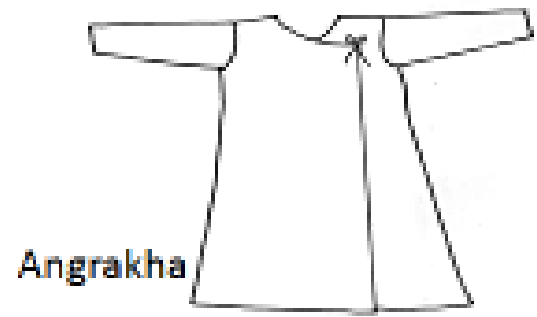

Fig. 2 Different Variations of Kameez worn in India

The salwar kameez is usually paired with a long, sheer fabric scarf or shawl known as a Dupatta, which is either draped across the neck or over the head which is both a mark of respect and honor. Decorative patterns may also be embroidered around the neckline, sleeves, hems and side slits of the outfit. Sometimes the Dupatta is not worn with the Salwar Kameez in a style where the Kameez is not fitted.

\subsection{Regional Variations}

Like all garments that have transformed with time, so has the salwar kameez. With its descent from the courtly to the everyday costume, it became more localized and the regional dress in the country, like in Punjab, Kashmir, Lucknow and Hyderabad. Originally a Muslim dress, the Salwar Kameez is popularly known as the Punjabi suit across India. But distinct regional variations are quite evident in the styles.

\subsubsection{Punjab}

The traditional dress of women in Punjab is the Salwar Kameez. The style popular in this region is the Kameez; a little above the knee with the Patiala Salwar. The sleeves are generally three quarters in length. The reason why the Patiala Salwar is preferred by most of the women of Punjab and other regions of Northern India is its comfort ability and durability in summers. Since the Patiala Salwar is very loose and stitched with pleats it is a very comfortable outfit to wear. The Dupatta is a very essential part of the Salwar Kameez in Punjab as the women are required to cover their heads especially in the presence of elders in the family. Bright colors are preferred by women of this region and the Dupatta is very heavily embroidered. Traditionally the most popular fabric for the dress is cotton fabric; but any type of fabric can be used as per the choice of the wearer. 


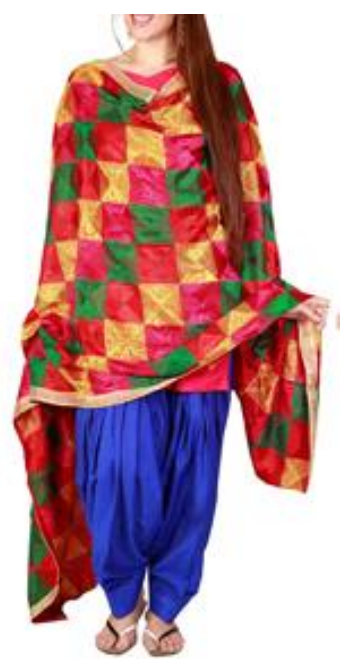

Fig. 3 Punjabi Suit

Source- http://zoompunjab.in/technology/item/34-traditional-dress-punjabi-women

\subsubsection{Kashmir}

The traditional dress of Jammu \& Kashmir is unique in the whole Indian Sub-Continent as it comes from various cultural backgrounds. The Kashmiri people usually practice Islam, Hinduism and Buddhism. Both Kashmiri Hindu and Muslim women dress up in Pheran- a loose Kalidar Kurta usually till knee length or longer. Salwar is worn as the lower garment. Pheran is considered a combination of Indian and Iranian clothing. The Pheran for Kashmiri women is more stunning and graceful with the heavy embroidery and has broad sleeves. The neckline, slits, sleeves and the hemline are elaborately embroidered. They have a very distinct way of wearing the scarf. The scarf is secured onto a skull cap with beautiful silver head ornaments. The Salwar is usually white in color. The Pheran is brightly colored and made from wool fabric. Sometimes the Pheran is worn over a Kurta.

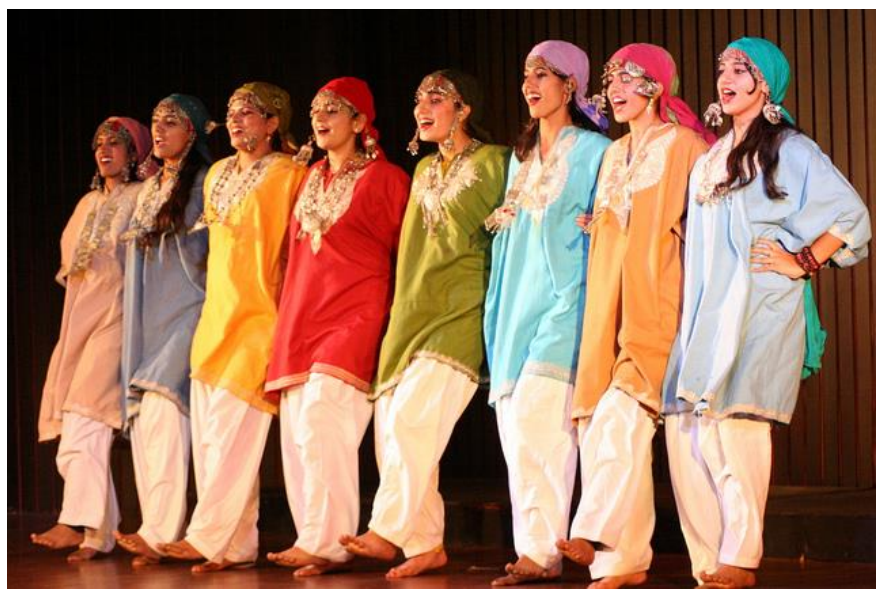

Fig.4 Kashmiri Pheran and Salwar

Source- http://thelovelyplanet.net/traditional-dress-of-jammu-kashmir/

\subsubsection{Lucknow}

Popularly known as the 'City of Nawabs', Lucknow is a Muslim dominated city in the state of Uttar Pradesh. The popular styles of this region are Anarkali Suit and the Lucknowi Kurta. The Anarkali is worn with the churidar. The Anarkali Suit; as commonly known, is usually longer in length. The Lucknowi Kurta has a slight variation from the Kalidar Kurta. The only difference is the triangular piece- 'Gusset' attached between the sleeve and the bodice. The Lucknowi Kurta is worn with the salwar. The most popular fabric for this style is 'mulmul' cotton. The dupatta is worn over both the shoulders making a cowl in the front. This region is also known for its traditional embroidery, which is extensively used on the garments both for men and women. 


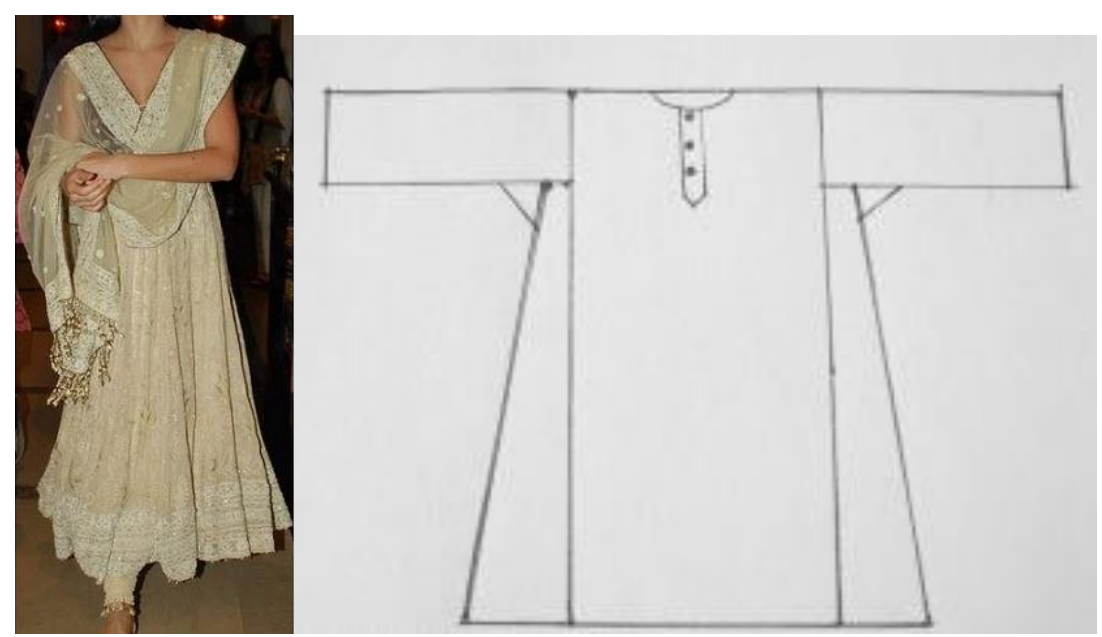

Fig. 5 Anarkali Suit and Lucknowi Kurta with Gusset

Source- http://www.lookinggoodfeelingfab.com/2015/02/max-fashion-icon-2015-lucknow.html https://seweverythingblog.wordpress.com/2013/10/25/the-kurta-the-kirtle-and-the-shift/

\subsubsection{Hyderabad}

Hyderabad, the city of Nizams, is the capital of Telengana state in the south of India has a rich heritage and history. It's a Muslim dominated city and the traditional dress of the Muslim bride is very fascinating and attractive. Khada Dupatta, literally meaning a scarf worn while standing. The most distinctive feature of the dress is the Dupatta which is six meters long and is draped over the Salwar Kurta in a manner that resembles a sari. Sometimes the Kurta is a two-piece ensemble with an inner blouse and a sleeveless tunic. It is believed that Mughal Empress Noor Jehan called Persian and Turkish craftsmen to India in the 17th century, and they passed the secret art of crafting royal Dupatta dresses only to their descendants. Later the begums of Nizams of Deccan adapted the original Mughal style, especially in the form of Khada Dupattas (Bipani, 2008). The Dupatta is the largest part of the outfit and is made of tissue material. Today, however, brides opt for net and even Banarasi dupattas since tissue does not fall gracefully. The colors preferred are usually golden yellow, red, and green. These traditional Hyderabadi Khada Dupattas are exemplary creations.

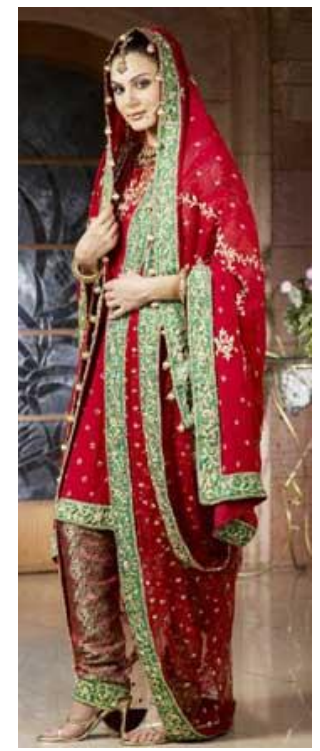

Fig 6- Khada Dupatta

Source- http://www.khadadupatta.com/contact-2/ 


\section{FASHION INFLUENCES ACROSS THE BORDERS}

The Indian subcontinent- India, Pakistan and Bangladesh share the same culture. After the partition in 1947, the three countries separated but still they are culturally connected in terms of cuisine, music and fashion. The Indian fashion Industry is flourishing and is been greatly followed by the fans of Bollywood across the borders. Huma Nassr, curator, Shaan -e -Pakistan in one of her interviews stated that the women in Pakistan look forward to the latest Bollywood trend in Salwar Kameez and Lehenga Choli. Lucknowi chikankari fabrics and Rajasthani Dupattas are the craze with the young generation. Similarly Yashica Dutt in her article reports that women in India are now wearing something that's loosely called 'Pakistani Suit' which has entirely changed the Indian Salwar suit mould. The Pakistani suits gained popularity since 2012 in the Indian market. She also quotes the manager of a famous clothing store in Delhi that Pakistani suits make for almost $30 \%$ of the total sales. The reason behind the popularity of Pakistani suits is their styling which is completely fresh. Unlike the Anarkali or the Patiala, the style is extremely form-flattering and has a crisp silhouette. The distinct differentiating elements between the Indian and Pakistani suits are-

$>$ Kurta- which falls straight and hides the ungainly bulges.

$>$ Salwar- Pant style and often lined with lace, unlike the Indian style which tapers narrowly.

$>$ Material- originally made in lawn and chiffon.

$>$ Silhouette- Loose, flowy and flattering all body shapes.

\section{CONCLUSION}

After extensive study and analysis, it can be easily inferred that the traditional dress of Persian (Iranian) and Turks travelled to the subcontinent during the medieval period. This easily got amalgamated into the culture of Indian subcontinent and with transformation over time, a unique style was created. Even though different from the original it still resembled the former in many ways. Amidst its royal grandeur, enigmatic feel and feminine charm Salwar Kameez, has an historical lineage. With its roots deeply seated in the antiquities of medieval India, the origin of Salwar Kameez still carries the rich sartorial chronicle amidst its fall, stitch, luster and feel. With its pristine origin hinting at the Mughal courtroom this dress has been synonymous along with the sari as the Indian National dress. For many modern day Indian women, the Salwar Kameez is regarded as a functional outfit that suits their modern lifestyle better than the traditional sari. Unlike the sari, the Salwar Kameez does not have strong association with tradition nor does it evoke anxieties of learning how to properly wrap and drape the outfit. Its ease of wearing has categorized it as practical office wear too, as it facilitates free movements.

\section{REFERENCE LIST}

A. (2013, June 05). Origin of Indian Salwar Kameez, Shalwar, Churidar kameez, In Fabric. Retrieved June 10, 2016, from https://ambadipba.wordpress.com/2013/05/30/origin-of-indian-salwar-kameez-shalwarchuridar-kameez-in-fabric/

Bipani, B. (2008, May 25). Spectrum [The gorgeous dupatta]. Retrieved August 16, 2016, from http://www.tribuneindia.com/2008/20080525/spectrum/society1.htm

Dongarkeri, K. S. (1959). The Indian Sari. New Delhi: All India Handicrafts Board.

Evolution of Indian Salwar Kameez. (n.d.). Retrieved February 18, 2015, from http://home.arcor.de/indiadisplay/information/salwar-evolution.html

Dutt, Y. (2014, July 19). Hindustan times [A Pakistani revolution on Indian soil]. Retrieved June 10, 2016 , from http://www.hindustantimes.com/brunch/a-pakistani-revolution-on-indian-soil/storyGy98nHfLxNBOq65xsGNCKL.html

Gupta, T. (2011). The Effect of British Raj on Indian Costume. Retrieved March 03, 2015, from http://www.fibre2fashion.com/industry-article/41/4022/the-effect-of-british1.asp

Ho, S. (2013, September 20). Salwar kameez. Retrieved June 10, 2016, from http://eresources.nlb.gov.sg/infopedia/articles/SIP_2013-09-20_164320.html

Jirousek, C. (2004). Islamic Clothing. In Encyclopaedia of Islam. Retrieved March 11 2013, from http://char.txa.cornell.edu/islamicclothes.htm 
IJASOS- International E-Journal of Advances in Social Sciences, Vol. II, Issue 6, December 2016

Kumar, R. (1999). Costumes and textiles of royal India. London: Christie's Books.

Lidhoo, P. (2015, September 9). Hindustan Times [Bridging borders with fashion expo at VK]. Retrieved September 9, 2015. 